University of Nebraska - Lincoln

DigitalCommons@University of Nebraska - Lincoln

\title{
Toxicity of Pb-Contaminated Soil to Japanese Quail (Coturnix japonica) and the Use of the Blood-dietary Pb Slope in Risk
}

\section{Assessment}

\author{
W. Nelson Beyer \\ U.S. Geological Survey \\ Yu Chen \\ U.S. Geological Survey \\ Paula Henry \\ U.S. Geological Survey \\ Thomas May \\ Columbia Environmental Research Center/Environmental Chemistry Branch \\ David Mosby \\ U.S. Fish and Wildlife
}

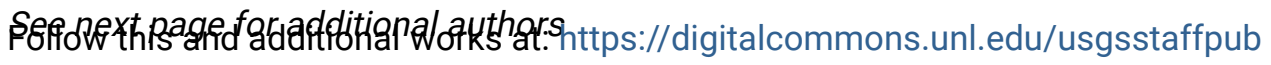 \\ Part of the Geology Commons, Oceanography and Atmospheric Sciences and Meteorology Commons, Other Earth Sciences Commons, and the Other Environmental Sciences Commons}

Beyer, W. Nelson; Chen, Yu; Henry, Paula; May, Thomas; Mosby, David; Rattner, Barnett A.; Shearn-Bochsler, Valerie I.; Sprague, Daniel; and Weber, John, "Toxicity of Pb-Contaminated Soil to Japanese Quail (Coturnix japonica) and the Use of the Blood-dietary Pb Slope in Risk Assessment" (2014). USGS Staff -Published Research. 961.

https://digitalcommons.unl.edu/usgsstaffpub/961

This Article is brought to you for free and open access by the US Geological Survey at DigitalCommons@University of Nebraska - Lincoln. It has been accepted for inclusion in USGS Staff -- Published Research by an authorized administrator of DigitalCommons@University of Nebraska - Lincoln. 


\section{Authors}

W. Nelson Beyer, Yu Chen, Paula Henry, Thomas May, David Mosby, Barnett A. Rattner, Valerie I. ShearnBochsler, Daniel Sprague, and John Weber 


\title{
Toxicity of Pb-Contaminated Soil to Japanese Quail (Coturnix japonica) and the Use of the Blood-dietary $\mathrm{Pb}$ Slope in Risk Assessment
}

\author{
W Nelson Beyer, ${ }^{*} \dagger$ Yu Chen, $\dagger$ Paula Henry, $\dagger$ Thomas May, $\ddagger$ David Mosby, $\&$ Barnett A Rattner, $\dagger$ \\ Valerie I Shearn-Bochsler, /| Daniel Sprague, $\dagger$ and John Weber\$ \\ †US Geological Survey, Patuxent Wildlife Research Center, Beltsville, Maryland, USA \\ tColumbia Environmental Research Center/Environmental Chemistry Branch, Columbia, Missouri, USA \\ ¿US Fish and Wildlife Service, Columbia, Missouri, USA \\ |/US Geological Survey, National Wildlife Health Center, Madison, Wisconsin, USA
}

(Submitted 20 February 2013; Returned for Revision 15 March 2013; Accepted 10 June 2013)

\begin{abstract}
This study relates tissue concentrations and toxic effects of $\mathrm{Pb}$ in Japanese quail (Coturnix japonica) to the dietary exposure of soil-borne $\mathrm{Pb}$ associated with mining and smelting. From $0 \%$ to $12 \%$ contaminated soil, by weight, was added to 5 experimental diets ( 0.12 to $382 \mathrm{mg} \mathrm{Pb} / \mathrm{kg}$, dry wt) and fed to the quail for 6 weeks. Benchmark doses associated with a 50\% reduction in delta-aminolevulinic acid dehydratase activity were $0.62 \mathrm{mg} \mathrm{Pb} / \mathrm{kg}$ in the blood, dry wt, and $27 \mathrm{mg} \mathrm{Pb} / \mathrm{kg}$ in the diet. Benchmark doses associated with a $20 \%$ increase in the concentration of erythrocyte protoporphyrin were $2.7 \mathrm{mg} \mathrm{Pb} / \mathrm{kg}$ in the blood and $152 \mathrm{mg} \mathrm{Pb} / \mathrm{kg}$ in the diet. The quail showed no other signs of toxicity (histopathological lesions, alterations in plasma-testosterone concentration, and body and organ weights). The relation of the blood $\mathrm{Pb}$ concentration to the soil $\mathrm{Pb}$ concentration was linear, with a slope of $0.013 \mathrm{mg} \mathrm{Pb} / \mathrm{kg}$ of blood (dry wt) divided by $\mathrm{mg} \mathrm{Pb} / \mathrm{kg}$ of diet. We suggest that this slope is potentially useful in ecological risk assessments on birds in the same way that the intake slope factor is an important parameter in risk assessments of children exposed to $\mathrm{Pb}$. The slope may also be used in a tissue-residue approach as an additional line of evidence in ecological risk assessment, supplementary to an estimate of hazard based on dietary toxicity reference values. Integr Environ Assess Manag 2014;10:22-29. Published 2013 SETAC.\#
\end{abstract}

Keywords: ALAD Protoporphyrin Liver Benchmark

\section{INTRODUCTION}

Concentrations of $\mathrm{Pb}$ in blood are used to estimate both exposure to $\mathrm{Pb}$ and its toxic effects in humans and in wildlife. When estimating hazards of $\mathrm{Pb}$ to children, assessors relate doses of $\mathrm{Pb}$ ingested to blood $\mathrm{Pb}$ concentrations which, in turn, provide a measure of the potential toxicity from $\mathrm{Pb}$. The "intake slope factor" refers to the slope of the regression of blood $\mathrm{Pb}$ concentration on dose (ATSDR 2007). Knowing this slope could be useful also in assessing risk to wild birds at contaminated sites, where tissue concentrations may be combined with risk assessment models to derive cleanup levels. We suggest that the blood-diet $\mathrm{Pb}$ slope may be adapted to ecological risk assessments of wildlife and provide a second line of evidence of hazard based on tissue concentrations. In this study, we relate dietary $\mathrm{Pb}$ concentrations to tissue concentrations and to toxic effects in Japanese quail (Coturnix japonica) fed soil contaminated with $\mathrm{Pb}$ from mining and smelting. We also discuss the implications of the findings to ecological risk assessment.

Most of the literature on $\mathrm{Pb}$ poisoning in birds addresses the toxicity of manmade artifacts of $\mathrm{Pb}$, such fishing sinkers, spent

* To whom correspondence may be addressed: NBeyer@usgs.gov

Published online 18 June 2013 in Wiley Online Library

(wileyonlinelibrary.com).

DOI: 10.1002/ieam. 1453

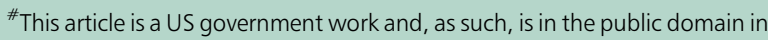
the United States of America. shot, and bullet fragments embedded in prey. At many $\mathrm{Pb}$ contaminated sites, however, such as those near old mines and smelters, the $\mathrm{Pb}$ is dispersed in the soil. Soil ingestion is the main pathway of exposure to $\mathrm{Pb}$ in children (Mielke and Reagan 1998) and in domestic animals (Smith et al. 2009). Ingestion of soil and sediment is also key to understanding hazards to wildlife at contaminated sites. Although some $\mathrm{Pb}$ is present in dietary items at contaminated sites, the concentrations in soil tend to be so much greater that the hazards to wildlife depend mainly on the rate of soil ingestion and on the concentration of $\mathrm{Pb}$ in the soil. Ecological risk assessments of $\mathrm{Pb}$ to wild birds at contaminated sites have generally focused on the birds that ingest the most soil. American robins (Turdus migratorius) (Hansen et al. 2011) and the American woodcock (Scolopax minor) are highly exposed target species that have been used in estimating preliminary remedial goals for cleaning up soil.

Blood $\mathrm{Pb}$ concentrations have been used in monitoring $\mathrm{Pb}$ in wild birds, including swans (O'Connell et al. 2008) and other waterfowl (Henny et al. 2000), raptors (Henny et al. 1991, 1994; Rattner et al. 2008), gulls (Burger and Gochfeld 1997), and songbirds (Johnson et al. 2007; Hansen et al. 2011). Blood $\mathrm{Pb}$ concentrations are thought to be a measure of short-term exposure to $\mathrm{Pb}$, but they are also used to estimate potential toxic effects (Buekers et al. 2009; Franson and Pain 2011). Blood Pb concentrations increase rapidly after dosing, within hours or days and, under constant exposure, remain approximately constant. In a 10-week study of mallards (Anas platyrhynchos) exposed to $\mathrm{Pb}$, Heinz (1999) found that 
mean blood $\mathrm{Pb}$ concentrations at 5 weeks were within $5 \%$ of the mean concentrations at 10 weeks. Lead concentrations in avian livers, as in blood, depend mainly on current exposure, but $\mathrm{Pb}$ concentrations in kidneys increase with time (Anders et al. 1982).

Although we also measured $\mathrm{Pb}$ in liver and kidneys in our study, we were particularly interested in the quantitative relation between the exposure to $\mathrm{Pb}$ and the resulting blood $\mathrm{Pb}$ concentration. Previous studies on mammals had consistently found a nonlinear relation, the slope decreasing with concentration, whereas the limited published data available on birds suggest a linear relation for $\mathrm{Pb}$. Knowing the relation is important not only for understanding the underlying toxicokinetics and for interpreting results from monitoring studies, but also for constructing quantitative ecological risk assessment models. Two bioindicators of $\mathrm{Pb}$ in the blood, the activity of red-blood cell delta-aminolevulinic acid dehydratase (ALAD) (Hoffman et al. 2000a) and the concentrations of erythrocyte protoporphyrin (Roscoe et al. 1979; Franson et al. 1986), were measured to quantify the toxicity associated with the blood $\mathrm{Pb}$ concentrations. A 50\% decrease in the activity of ALAD of a population of birds or mammals is defined as injury in the Natural Resource Damage Assessment (1995) regulations (15 C. F. R. § 11.62 (f) (4) (v) (D)). An increase in erythrocyte protoporphyrin concentration is considered evidence of injury to the hematopoietic system (Anders et al. 1982).

Several controlled studies have examined the uptake of $\mathrm{Pb}$ from contaminated soil by mammals (Casteel et al. 2006), but less is known about uptake by birds. Pigeons (Columbia livia) dosed with capsules of soil contaminated with $\mathrm{Pb}$ from a small arms range ( $5400 \mu \mathrm{g} \mathrm{Pb}$ for 14 days) developed a mean blood $\mathrm{Pb}$ concentration of $0.89 \mu \mathrm{g} / \mathrm{dL}$ and an increase in erythrocyte protoporphyrin concentration (Bannon et al. 2011). Several feeding studies have been conducted on $\mathrm{Pb}$-contaminated sediments from the Coeur d'Alene River Basin, which were dried, mixed into diets, and fed to waterfowl under controlled conditions (Heinz 1999; Hoffman et al. 2000a; Day et al. 2003). Connor et al. (1994) found that northern bobwhite (Colinus virginianus) fed a diet containing $8 \%$ of other sediment ( $4500 \mathrm{mg} \mathrm{Pb} / \mathrm{kg}$ ) from the Coeur d'Alene River Basin accumulated a mean of $1.26 \mathrm{mg} \mathrm{Pb} / \mathrm{kg}$ (wet wt) in their blood.

Our objectives were to: 1) evaluate the toxicity of $\mathrm{Pb}$ contaminated soil fed to Japanese quail, 2) estimate the benchmark doses (Filipsson et al. 2003) in diet and in blood associated with decreased activity of ALAD and increased concentrations of erythrocyte protoporphyrin, 3) estimate the blood-dietary $\mathrm{Pb}$ slope, and 4) suggest how this slope may be used in ecological risk assessment.

\section{METHODS}

\section{Quail and diets}

Surface soil for the study was collected with a spade from the Viburnum Trend, just southeast of the Buick Smelter, in the Mark Twain National Forest ( $37^{\circ} 49^{\prime} 4.4^{\prime \prime} \mathrm{N}, 90^{\circ} 44^{\prime} 16.7^{\prime \prime} \mathrm{W}$ ), $\mathrm{MO}$, on January 14, 2010. This soil was passed through a 2-mm sieve and a sample was sent to the Agricultural Analytical Services Laboratory of The Pennsylvania State University (University Park, PA) where soil $\mathrm{pH}$, cation exchange capacity, organic matter content, and texture were determined. The Purina Game Bird Maintenance Chow (St. Louis, MO) selected for the study was a nutritionally complete mash diet for
Japanese quail, with a minimum crude protein content of $12.5 \%$ and from $0.5 \%$ to $1 \% \mathrm{Ca}$. Because the quail might have preferentially selected larger particles of the mash and less soil from chow while feeding, we pelletized the diets, ensuring that the quail did ingest soil at the nominal rates. Water and cracked corn were added to the chow to produce a reference diet that could be pressed into stable pellets through a $6-\mathrm{mm}$ die in a laboratory feed pelletizer. The pelletized control diet was $63 \%$ chow (dry wt), 27\% corn (dry wt), and 10\% water. Treated diets had the sieved soil added at the rates of $2 \%, 4 \%, 8 \%$, or $12 \%$ as a fraction of the total dry wt of the diet. To form firm pellets, we added small amounts of water as required, as the soil content increased. Pellets were preserved frozen until they were fed to the quail. Samples of the soil and the mixed diets were sent to the Columbia Environmental Research Center in Missouri for analyses of metals.

Male quail were acquired from a breeding colony that had come from MA Ottinger, University of Maryland (College Park, MD). All procedures involving the handling of quail were reviewed and approved by the USGS Patuxent Wildlife Research Center's Animal Care and Use Committee. Twentythree-day-old quail were acclimated to test conditions in separate stainless steel cages $(23 \mathrm{~cm}$ wide $\times 38 \mathrm{~cm}$ deep $\times 33$ $\mathrm{cm}$ height) for 5 days while weights were monitored. From those quail that maintained or increased their weight, we randomly assigned 304 -week-old birds to the treatments. Each quail had access to its own set of semicircular feed and water cups hooked to the outside door panel, and feed and clean water were provided ad libitum. Automatic lights were set to provide a daily photoperiod of $16 \mathrm{~h}$ of light per day and temperature was maintained at $21^{\circ} \mathrm{C}$. The trial ran for 6 weeks, beginning on November 22, 2010. Quail were observed and cared for daily.

At the end of the trial, quail were weighed and approximately $1.0 \mathrm{~mL}$ of blood was drawn from the jugular vein into a tuberculin syringe using a 25 gauge needle containing heparin (1000 USP units/mL; Sargent Pharmaceuticals, Schaumburg, IL) in the needle hub. Then the quail were euthanized with carbon dioxide followed by cervical dislocation. Subsamples of blood were apportioned as follows: $200 \mu \mathrm{L}$ for chemical analysis, $75 \mu \mathrm{L}$ for microhematocrit, $200 \mu \mathrm{L}$ for ALAD, $50 \mu \mathrm{L}$ for protoporphyrin, and $250 \mu \mathrm{L}$ for testosterone. Cryotubes containing whole blood for ALAD assays were frozen in liquid $\mathrm{N}$ and then stored in an ultralow freezer at $-80^{\circ} \mathrm{C}$. Quail livers, kidneys, hearts, and testes were removed from the carcass and weighed. Portions of the blood, kidneys, and livers were sent to Columbia Environmental Research Center in Missouri for analyses of metals. Portions of the kidneys, livers, heart, and testes were preserved in 10\% formalin and sent to the National Wildlife Health Center in Madison, Wisconsin, to be sectioned, stained, and examined for histopathological changes.

\section{Biochemistry and pathology}

Testosterone concentrations were determined in plasma samples by an enzyme-linked immunosorbent assay (ELISA) (DRG testosterone ELISA kit, EIA-1559; DRG International, Mountainside, NJ) with minor modifications of the manufacturer's protocol. Plasma had been isolated from the whole blood samples by centrifugation and then duplicate aliquots of $75 \mu \mathrm{L}$ of plasma and enzyme-conjugated testosterone solution were mixed in wells of an antibody-coated microplate. The mixture was discarded after $90 \mathrm{~min}$ incubation at room temperature and the plate was washed. Substrate solution 
was added to the wells, incubated for $20 \mathrm{~min}$, and then the reaction was halted with the addition of stop solution. The optical density of each well was read at $450 \pm 10 \mathrm{~nm}$. The detection limit of the testosterone assay was $0.23 \mathrm{ng} / \mathrm{mL}$, the recovery was $112 \%$, the mean intra-CV was $10.9 \%$, and the interassay CV was 16.3\%. Proctodeal glands of male quail produce "foam," which is transferred to females during insemination. Foam production for each male was estimated qualitatively, on a scale of $0-3$, based on the percent of fecal material with foam deposits; a score of $0=$ no foam, $1=1 \%$ $5 \%, 2=6 \%-50 \%$, and $3=>50 \%$ of fecal matter covered with foam deposits (Henry et al. 2012).

Red blood cell ALAD activity was measured as described by Burch and Siegel (1971) and as modified by Pain (1987), with enzyme activity optimized by use of $\mathrm{pH} 6.65$ sodium phosphate buffer. One unit of activity equals an increase in absorbance of 0.100 at $555 \mathrm{~nm}$ wave length with a $1.0-\mathrm{cm}$ light path $/ \mathrm{mL}$ of red blood cells $/ \mathrm{h}$ at $38^{\circ} \mathrm{C}$. The average relative percent difference of the duplicate measures of activity was 6.6. Erythrocyte protoporphyrin concentration $(\mu \mathrm{g} / \mathrm{dL})$ was quantified with a hematofluorometer (AVIV Biomedical, Lakewood, NJ) modified according to Roscoe et al. (1979). The average relative percent difference of the duplicate concentrations was 3.7.

Tissue samples from liver, kidney, heart, and testes were fixed in $10 \%$ formalin, embedded in paraffin, cut at $5 \mu \mathrm{m}$, and stained with hematoxylin and eosin, as well as Ziehl-Neelson and Fite's acid-fast stains.

\section{Metal analyses}

All tissue samples were lyophilized to a constant weight and then homogenized to a powder consistency with a glass rod. A 40-60 mg dried subsample of blood, liver, or kidney was weighed into a $10-\mathrm{mL}$ Teflon-lined, screw-cap borosilicate test tube and $1.0 \mathrm{~mL}$ subboiled $\mathrm{HNO}_{3}$ was added. After a $1-\mathrm{h}$ predigestion at room temperature, the tube was sealed and placed in a hot-block heater at $110^{\circ} \mathrm{C}$ for $30 \mathrm{~min}$. The tube was cooled for $10 \mathrm{~min}, 0.2 \mathrm{~mL}$ high-purity $\mathrm{H}_{2} \mathrm{O}_{2}$ was added, and the tube was returned to the hot-block for $30 \mathrm{~min}$. After cooling, the sample was diluted to a final volume of $10 \mathrm{~mL}$ for a final acid matrix of $10 \% \mathrm{HNO}_{3}$ (Brumbaugh et al. 2005). Subsamples of dried feed $(0.25 \mathrm{~g})$ were digested in sealed Teflon pressure vessels with $6 \mathrm{~mL} \mathrm{HNO}_{3}$ in a microwave digestion system. The samples were then diluted to $100 \mathrm{~mL}$ with deionized water for a final acid matrix of $6 \% \mathrm{HNO}_{3}$. Subsamples of dried soil $(0.2 \mathrm{~g})$ were digested in a sealed Teflon pressure vessel with $5.5 \mathrm{~mL}$ $\mathrm{HNO}_{3}$ and $0.5 \mathrm{~mL} \mathrm{HCl}$ in a microwave digestion system. The samples were diluted to $100 \mathrm{~mL}$ with deionized water for a final acid matrix of $5.5 \% \mathrm{HNO}_{3}-0.5 \% \mathrm{HCl}$ (Besser et al. 2007; Brumbaugh et al. 2007).

Concentrations of $\mathrm{Cu}, \mathrm{Zn}, \mathrm{Cd}$, and $\mathrm{Pb}$ (blood, liver, kidney, and feed) and $\mathrm{Al}, \mathrm{Fe}, \mathrm{Cu}, \mathrm{Ni}, \mathrm{Zn}, \mathrm{Cd}$, and $\mathrm{Pb}$ (soil) were determined using a PE/SCIEX Elan 6000 ICP-DRC-MS (PerkinElmer Corporation, Norwalk, CT). Samples were automatically delivered to the ICP-MS by means of a software-controlled CETAC ASD-500 autosampler/autodiluter system (Cetac Technologies, Omaha, NE). All sample digestates were analyzed with $10 \times$ predilution by the autodiluter (Brumbaugh et al. 2005, 2007).

Method accuracy was determined through the use of standard reference materials (SRM): blood: Seronorm Trace Elements 201705 Whole Blood 3, Clinchek 8841 Whole Blood Control Level II; liver and kidney: National Institute of
Standards and Technology (NIST) 1577 and 1577b bovine liver, National Research Council Canada (NRCC) TORT-1 lobster hepatopancreas; feed: NIST 1577 bovine liver, NRCC TORT-1 lobster hepatopancreas; soil: NRCC MESS-3 marine sediment, NRCC PACS-1 marine sediment, NIST 2709 San Joaquin soil. Three standard reference materials were run with each batch of tissue. Recoveries of $\mathrm{Pb}$ from SRMs ran with blood and kidney, and $\mathrm{Cu}, \mathrm{Zn}, \mathrm{Cd}$, and $\mathrm{Pb}$ from SRMs ran with liver, ranged from $94 \%$ to $160 \%$ and averaged $102 \% \pm 14 \%$ (standard deviation [SD]). Recoveries of $\mathrm{Cu}, \mathrm{Zn}, \mathrm{Cd}$, and $\mathrm{Pb}$ from SRMs ran with feed samples ranged from $93 \%$ to $105 \%$ and averaged $99 \% \pm 3 \%$. Recoveries of $\mathrm{Fe}, \mathrm{Cu}, \mathrm{Ni}, \mathrm{Zn}, \mathrm{Cd}$, and $\mathrm{Pb}$ from SRMs ran with soil ranged from $73 \%$ to $100 \%$ and averaged $93 \% \pm 8 \%$. The recovery of $\mathrm{Al}$ from SRMs ran with soil samples was considerably poorer $(34 \%$ and $41 \%$ ) because a total recoverable acid digestion procedure was used (similar to the US Environmental Protection Agency's (USEPA 1997) method 305la), which yields acid insoluble residue and thus low recoveries for this element. Method accuracy was also accessed through the use of sample predigestion spikes or method spikes. Ranges and mean \pm SD of spike recoveries for each matrix were as follows: blood: $96 \%$ to $102 \%$, $100 \% \pm 2.2 \%$; kidney: $103 \%$ to $111 \%, 106 \% \pm 4.3 \%$; liver: $98 \%$ to $106 \%, 101 \% \pm 2.1 \%$; feed: $79 \%$ to $121 \%, 98 \% \pm 6.4 \%$; soil: $81 \%$ to $110 \%, 94 \% \pm 7 \%$. Method precision was evaluated by either duplicate or triplicate digestion and analysis of samples. Ranges and mean $\pm \mathrm{SD}$ of relative percent differences (RPD) or percent relative standard deviations (\%RSD) for each matrix were as follows: blood: $2.2 \%$ to $39 \%, 14 \% \pm 14 \%$; kidney: $6 \%$ to $12.5 \%, 9.7 \% \pm 2.5 \%$; liver: $0.4 \%$ to $7.3 \%$, $3.6 \% \pm 2.3 \%$; feed: $1.6 \%$ to $32 \%, 10 \% \pm 8.5 \%$; soil: $0.6 \%$ to $34 \%, 8.5 \% \pm 9.2 \%$. Metal concentrations were reported as $\mathrm{mg} / \mathrm{kg}$, dry wt.

\section{Statistics}

Differences in mean metal tissue concentrations among treatment groups were compared with a Kruskal-Wallis analysis of variance on ranks. Protoporphyrin concentrations and ALAD activities were transformed to logs and then analyzed by an analysis of variance with the Holm-Sidak method to identify significant differences from control values. Blood, hepatic and renal $\mathrm{Pb}$ concentrations were linearly regressed on dietary $\mathrm{Pb}$ concentrations. All of these statistical calculations were run on SigmaPlot 9.0 and SigmaStat 3.1 software (Systat Software, San Jose, CA).

We used software (Benchmark Dose Software version 2.3.1) developed by the US Environmental Protection Agency (USEPA) (http://www.epa.gov/ncea/bmds/index.html) to estimate benchmark reference concentrations, expressed as $\mathrm{Pb}$ concentrations in both the diet and blood, associated with a predetermined benchmark response. The values of ALAD activity and erythrocyte protoporphyrin concentration were regressed on dietary $\mathrm{Pb}$ concentrations and on blood $\mathrm{Pb}$ concentrations using a series of regression equations. The bestfitting function for each variable was selected using the Akaike information criterion. Then the benchmarks associated with a $20 \%$ increase in the concentration of erythrocyte protoporphyrin and a 50\% reduction in the activity of ALAD were estimated from the equations. The 20\% decrease in protoporphyrin concentration was selected following the USEPA guidance (USEPA 2003) for developing soil screening levels and the 50\% decrease in the activity of ALAD of a population of birds or mammals was selected because of its inclusion as an identified 
Table 1. Mean $(N=4) \mathrm{Pb}, \mathrm{Zn}, \mathrm{Cd}$, and $\mathrm{Cu}$ concentrations in diets amended with increasing percentages of contaminated soil

\begin{tabular}{|c|c|c|c|c|}
\hline Soil content of diet & $\begin{array}{c}\mathrm{Pb} \\
\mathrm{mg} / \mathrm{kg} \text { (dry wt) }\end{array}$ & $\begin{array}{c}\mathrm{Cd} \\
\mathrm{mg} / \mathrm{kg}(\text { dry w) }\end{array}$ & $\begin{array}{c}\mathrm{Zn} \\
\mathrm{mg} / \mathrm{kg} \text { (dry wt) }\end{array}$ & $\begin{array}{c}\mathrm{Cu} \\
\mathrm{mg} / \mathrm{kg} \text { (dry wt) }\end{array}$ \\
\hline Control & 0.12 & 0.07 & 74 & 11 \\
\hline $2 \%$ & 74 & 0.22 & 85 & 13 \\
\hline $4 \%$ & 125 & 0.31 & 76 & 11 \\
\hline $8 \%$ & 269 & 0.61 & 95 & 18 \\
\hline $12 \%$ & 382 & 0.84 & 95 & 18 \\
\hline
\end{tabular}

injury in the Natural Resource Damage Assessment Regulations (15 C. F. R. $\S 11.62$ (f) (4) (v) (D)).

\section{RESULTS}

\section{Toxic effects}

The experimental soil from Viburnum Trend, a loam, had a $\mathrm{pH}$ of 5.0, a cation exchange capacity of 14 (meq/100 g), and an organic matter content of $12 \%$. It contained $3720 \mathrm{mg} \mathrm{Pb} / \mathrm{kg}$, the major contaminant at the site, $264 \mathrm{mg} \mathrm{Zn} / \mathrm{kg}$, $7.2 \mathrm{mg} \mathrm{Cd} / \mathrm{kg}$, and $98 \mathrm{mg} \mathrm{Cu} / \mathrm{kg}$, dry wt. The treated diets contained concentrations of $\mathrm{Pb}(74-382 \mathrm{mg} / \mathrm{kg})$ that were consistent with but slightly below concentrations expected from their soil contents (Table 1). The adjusted $r$-square of the correlation between percent soil in the diet and the $\mathrm{Pb}$ concentration of the diet was $99 \%$. The other metals measured in the diet were not likely to be toxic to the quail. The highest dietary concentrations of $\mathrm{Zn}$ and $\mathrm{Cu}$ in the study, in the 12\% soil group, were less than twice the concentrations of those metals in the control diets (Table 1). Dietary concentrations of Cd showed a greater increase with soil content but, nonetheless, the 12\%-soil diet contained only $0.84 \mathrm{mg} \mathrm{Cd} / \mathrm{kg}$. Hepatic $\mathrm{Cd}$ concentrations increased significantly with dietary soil content but hepatic $\mathrm{Zn}$ and $\mathrm{Cu}$ concentrations did not (Table 2). The highest observed mean hepatic Cd concentration, of $2.1 \mathrm{mg} / \mathrm{kg}$, dry wt (Table 2), was well below the injury threshold (range of $45-70 \mathrm{mg} \mathrm{Cd} / \mathrm{kg}$, wet wt) suggested by Wayland and Scheuhammer (2011).

Quail gained an average of $48 \%$ of their weight (from $71 \mathrm{~g}$ to $105 \mathrm{~g}$ ) over the 6 weeks and all birds appeared normal throughout the trial. Similar aged Japanese quail from the parent colony ate approximately $16 \mathrm{~g}$ of diet per day. The weight gains, ratios of organ weights (liver, kidney, heart, testes) to body weights, hematocrits, and foam production of the
$\mathrm{Pb}$-exposed quail were statistically indistinguishable $(p>0.05)$ from control values. Average plasma testosterone concentrations for all treatment groups were within $1.4-2.02 \mathrm{ng} / \mathrm{mL}$, with no significant differences between the treated groups and the control $(F[4,23]=0.22, p=0.93)$. Testosterone concentrations were consistent with those measured in control birds from the colony; young, unpaired 8-week-old control males from the colony had a lower average plasma testosterone concentration of $0.92 \mathrm{ng} / \mathrm{mL}$ and actively breeding adult control males had values between $2.3-3.5 \mathrm{ng} / \mathrm{mL}$. No histologic lesions were observed in testes and hearts. Lesions observed in livers (hepatocellular hydropic degeneration and lipidosis) and kidneys (proximal tubular epithelial cell vacuolation, necrosis, and hemosiderosis) bore no relation to treatment levels and were probably not caused by exposure to $\mathrm{Pb}$. We observed neither the nephrosis reported in $\mathrm{Pb}$-poisoned Japanese quail (Almansour 2008) nor the renal nuclear inclusion bodies reported in Pb-poisoned northern bobwhite (Beyer et al. 1988).

Lead had physiological effects on the blood; all quail groups exposed to $\mathrm{Pb}$-contaminated soil had a significantly lower mean ALAD activity than did the control group $(p<0.05)$. Activity of ALAD decreased with dose, from 222 units in control quail to 5 units in the $12 \%$ soil group (Table 3 ). The benchmark doses associated with a $50 \%$ reduction in ALAD activity were $0.62 \mathrm{mg} \mathrm{Pb} / \mathrm{kg}$ in the blood and $27 \mathrm{mg} \mathrm{Pb} / \mathrm{kg}$ in the diet, based on the exponential function. Mean protoporphyrin concentrations increased at higher $\mathrm{Pb}$ doses, to approximately double the control mean at the highest dietary $\mathrm{Pb}$ concentration. The benchmark doses associated with a $20 \%$ increase in the concentration of erythrocyte protoporphyrin were $2.7 \mathrm{mg} \mathrm{Pb} /$ $\mathrm{kg}$ in the blood and $152 \mathrm{mg} \mathrm{Pb} / \mathrm{kg}$ in the diet, based on the Hill function. The lower 95\% confidence limits of the benchmarks were slightly lower: ALAD, $0.58 \mathrm{mg} \mathrm{Pb} / \mathrm{kg}$ in the blood and

Table 2. Hepatic metal concentrations in Japanese quail fed Pb-contaminated soil at $0 \%$ to $12 \%$ in the diet for 6 weeks

\begin{tabular}{|c|c|c|c|c|}
\hline Soil content of diet & $\begin{array}{c}\text { Hepatic Pb } \\
\text { mg/kg (dry wt) }\end{array}$ & $\begin{array}{c}\text { Hepatic Cd } \\
\mathrm{mg} / \mathrm{kg} \text { (dry wt) }\end{array}$ & $\begin{array}{c}\text { Hepatic Zn } \\
\text { mg/kg (dry wt) }\end{array}$ & $\begin{array}{c}\text { Hepatic Cu } \\
\text { mg/kg (dry wt) }\end{array}$ \\
\hline Control & 0.01 & 0.25 & 66 & 15 \\
\hline $2 \%$ & 3.3 & 0.61 & 62 & 14 \\
\hline $4 \%$ & 7.3 & 1.0 & 67 & 15 \\
\hline $8 \%$ & 9.1 & 1.3 & 62 & 14 \\
\hline $12 \%$ & 12 & 2.1 & 68 & 16 \\
\hline Significant by Kruskal-Wallis test at $p<0.05, N=6$ per group & Yes & Yes & No & No \\
\hline
\end{tabular}


Table 3. Tissue concentrations of $\mathrm{Pb}(\mathrm{mg} / \mathrm{kg}$, dry wt), erythrocyte ALAD activity, and protoporphyrin concentrations in Japanese quail fed $\mathrm{Pb}$-contaminated soil at $0 \%-12 \%$ in the $\operatorname{diet}(N=6$ per group)

\begin{tabular}{|c|c|c|c|c|c|}
\hline Treatment & $\begin{array}{c}\text { Blood } \\
\mathrm{Pb}\end{array}$ & $\begin{array}{c}\text { Hepatic } \\
\text { Pb }\end{array}$ & $\begin{array}{l}\text { Renal } \\
\mathrm{Pb}\end{array}$ & $\begin{array}{l}\text { ALAD activity }{ }^{a} \\
\left.\text { (units }{ }^{b}\right)\end{array}$ & $\begin{array}{c}\text { Protoporphyrin } \\
(\mu \mathrm{g} / \mathrm{dL})\end{array}$ \\
\hline Control & 0.12 & 0.01 & 0.03 & 222 & 342 \\
\hline $2 \%$ soil & 1.4 & 3.3 & 11 & $37^{* b}$ & 339 \\
\hline $4 \%$ soil & 2.5 & 7.3 & 18 & $13^{*}$ & 374 \\
\hline $8 \%$ soil & 3.2 & 9.1 & 33 & $7^{*}$ & $626^{*}$ \\
\hline $12 \%$ soil & 5.4 & 12 & 48 & $5^{*}$ & $687^{*}$ \\
\hline Statistically significant ANOVA $(p<0.05)$ & Yes $^{c}$ & Yes $^{c}$ & Yes $^{c}$ & Yes & Yes \\
\hline
\end{tabular}

${ }^{a}$ One unit of activity equals an increase in absorbance of 0.100 at $555 \mathrm{~nm}$ wave length with a $1.0-\mathrm{cm}$ light path $/ \mathrm{ml}$ of red blood cells $/ \mathrm{h}$ at $38^{\circ} \mathrm{C}$.

${ }^{\mathrm{b}}$ Asterisk signifies a significant difference from the reference value by the Holm-Sidak method at $p<0.05$, performed after a significant ANOVA. Units of ALAD activity were log-transformed.

cKruskal-Wallis analysis of variance on ranks.

$25 \mathrm{mg} \mathrm{Pb} / \mathrm{kg}$ in the diet; protoporphyrin, $2.5 \mathrm{mg} \mathrm{Pb} / \mathrm{kg}$ in the blood and $117 \mathrm{mg} \mathrm{Pb/kg}$ in the diet.

\section{Relation of tissue $\mathrm{Pb}$ concentrations to dietary $\mathrm{Pb}$ concentrations}

Concentrations of $\mathrm{Pb}$ in blood, liver, and kidney increased with dietary soil content (Table 3 and Figure 1), with adjusted

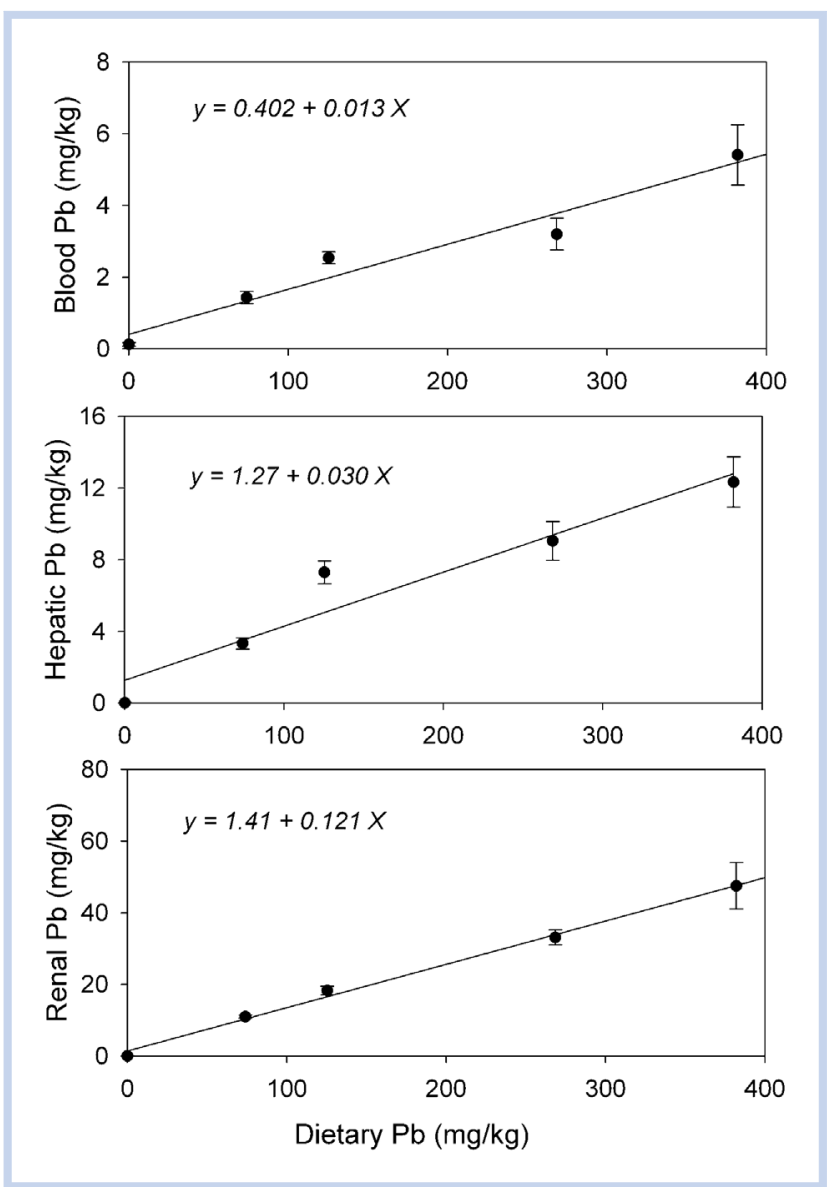

Figure 1. Regressions of blood, hepatic, and renal Pb concentrations on dietary $\mathrm{Pb}$ of Japanese quail fed increasing percentages of contaminated soil. Note that the regressions are linear and that the control concentrations are close to zero. The adjusted $r$-squares are 0.97 (blood), 0.96 (liver), and 0.99 (kidneys), all significant at $p<0.01$. $r$-squares of 0.97 (blood), 0.96 (liver), and 0.99 (kidneys). All of the relations appeared to be linear. The slope of the regression (Figure 1) of blood $\mathrm{Pb}$ concentration divided by dietary $\mathrm{Pb}$ concentration was 0.013 (mg Pb/kg of blood, dry wt, divided by $\mathrm{mg} \mathrm{Pb} / \mathrm{kg}$ of diet). Blood-dietary $\mathrm{Pb}$ slopes were calculated from data published in 8 other $\mathrm{Pb}$ dietary feeding studies on wildlife for comparison (Table 4). All of these slopes apply to chronic exposures to $\mathrm{Pb}$ in nutritionally complete commercial diets and were based on at least 3 pairs of data. The slope for our Japanese quail was converted to wet wt $(0.0027 \mathrm{mg} \mathrm{Pb} / \mathrm{kg}$ blood, wet wt, divided by $\mathrm{mg} \mathrm{Pb} / \mathrm{kg}$ of diet), based on a measured $79 \%$ moisture content of the blood. The median of the slopes was $0.0036 \mathrm{mg} \mathrm{Pb} / \mathrm{kg}$ blood, wet wt, divided by $\mathrm{mg}$ $\mathrm{Pb} / \mathrm{kg}$ diet and all of the values were between 0.0015 and 0.0072 .

\section{DISCUSSION}

\section{Toxic effects}

At low levels of exposure to $\mathrm{Pb}$, Japanese quail, like mallards, experience reduced activity of ALAD and, when exposed to greater $\mathrm{Pb}$ concentrations, an increase in erythrocyte protoporphyrin (Heinz 1999). The lack of other observed signs of toxicity in the quail is consistent with earlier studies suggesting that galliforms (turkeys, pheasants, quail, and chickens) are relatively resistant to $\mathrm{Pb}$ poisoning (Franson and Pain 2011), except for egg production. In a 5-week feeding trial, for example, Japanese quail developed anemia and weighed less than controls, but only when fed $500 \mathrm{mg} \mathrm{Pb} / \mathrm{kg}$ as $\mathrm{Pb}$ acetate (Morgan et al. 1975). Weights of their testes were reduced only at a dietary $\mathrm{Pb}$ concentration of $1000 \mathrm{mg} / \mathrm{kg}$. Lead nitrate and $\mathrm{Pb}$ subacetate caused no overt signs of toxicity in 2-week-old Japanese quail fed a diet containing $5000 \mathrm{mg} \mathrm{Pb} / \mathrm{kg}$ over 5 days (Hill and Camardese 1986). In addition, tissue $\mathrm{Pb}$ concentrations associated with injury tend to be higher in northern bobwhite quail than in other avian species; median $\mathrm{Pb}$ concentrations associated with death reported in livers $(102 \mathrm{mg} / \mathrm{kg})$ and kidneys $(185 \mathrm{mg} / \mathrm{kg}$ ) of bobwhite were greater than corresponding concentrations in livers $(22-44 \mathrm{mg} / \mathrm{kg})$ and kidneys (22-140 mg/kg) of 5 other avian species (Beyer et al. 1988). The rate of egg production in Japanese quail, however, is extremely sensitive to $\mathrm{Pb}$; as little as $1 \mathrm{mg} \mathrm{Pb} / \mathrm{kg}$ in the diet significantly decreases the number of eggs laid (Edens et al. 1976). In contrast, as much as $1000 \mathrm{mg} \mathrm{Pb/kg}$ in the same 
Table 4. Blood-diet slopes of regressions ( $\mathrm{mg} \mathrm{Pb} / \mathrm{kg}$ blood, wet wt $-\mathrm{mg} \mathrm{Pb} / \mathrm{kg}$ diet) of Japanese quail fed $\mathrm{Pb}$ in their diets

\begin{tabular}{|c|c|c|c|c|c|}
\hline Species & $\mathrm{Pb}$ Source & $\begin{array}{c}\text { Dietary Pb } \\
\text { mg/kg }\end{array}$ & $\begin{array}{c}\text { Blood Pb } \\
\text { mg/kg (wet) }\end{array}$ & Slope & Reference \\
\hline Japanese quail & $\begin{array}{l}\text { Mining and smelting } \\
\text { soil (MO) }\end{array}$ & $\begin{array}{c}0.12,74,125 \\
269,382\end{array}$ & $\begin{array}{c}0.026,0.30,0.53 \\
0.67,1.14\end{array}$ & 0.0027 & This study \\
\hline $\begin{array}{l}\text { Canada Goose } \\
\text { (goslings) }^{a}\end{array}$ & $\begin{array}{l}\text { Coeur d'Alene } \\
\text { sediment }\end{array}$ & $3,414,828,1656$ & $0.03,0.681 .61,2.52$ & 0.0015 & $\begin{array}{l}\text { (Hoffman et al. } \\
2000 \text { b) }\end{array}$ \\
\hline Mallard duckling & Coeur d'Alene sediment & $3,417,831$ & $0.03,1.41,2.56$ & 0.0031 & $\begin{array}{l}\text { (Hoffman et al. } \\
2000 \text { a) }\end{array}$ \\
\hline Mallard (subadult) & $\begin{array}{l}\text { Coeur d'Alene } \\
\text { sediment (exp. 2) }\end{array}$ & $8.7,642,1284$ & $0.09,3,6.8$ & 0.0053 & (Heinz 1999) \\
\hline Mallard (subadult) & $\begin{array}{l}\text { Coeur d'Alene } \\
\text { sediment (exp. 1) }\end{array}$ & $\begin{array}{c}1.5,103,207 \\
414,828\end{array}$ & $\begin{array}{c}0.04,0.99,1.7 \\
2.9,6.1\end{array}$ & 0.0072 & (Heinz 1999) \\
\hline Mallard & $\mathrm{Pb}$ nitrate & $1,5,25$ & $27,55,138$ & 0.0049 & (Finley et al. 1976) \\
\hline Mute swan ${ }^{b}$ & Coeur d'Alene sediment & $5.8,460,850$ & $0.20,1.28,2.3$ & 0.0025 & (Day et al. 2003) \\
\hline Broiler chickens & $\mathrm{Pb}$ acetate & $3.9,4.9,14,104$ & $0.04,0.13,0.18,0.50$ & 0.0040 & (Bakalli et al. 1995) \\
\hline Deer mice $^{c}$ & $\mathrm{~Pb}$ acetate & $0.12,1.313,133$ & $0.006,0.013,0.43,0.50$ & 0.0036 & (McBride 2007) \\
\hline
\end{tabular}

${ }^{a}$ Branta canadensis.

${ }^{\mathrm{b}}$ Cygnus olor.

'Peromyscus maniculatus.

study did not reduce growth in males. The USEPA (2005) calculated an ecological soil screening level (eco-SSL) of $11 \mathrm{mg}$ $\mathrm{Pb} / \mathrm{kg}$ of soil based on reproductive effects observed in Japanese quail and chickens fed extremely low concentrations of $\mathrm{Pb}$ (Edens and Garlich 1983). This concentration of $11 \mathrm{mg} / \mathrm{kg}$ is below the national average of $19 \mathrm{mg} \mathrm{Pb} / \mathrm{kg}$ in surficial materials (Shacklette and Boerngen 1984) and implies that background concentrations of soil $\mathrm{Pb}$ are toxic to wild birds that ingest a large amount of soil as they feed. In general, the rate of egg production is not a sensitive endpoint to $\mathrm{Pb}$ toxicity in birds other than galliforms; treatment of mallards with a number $4 \mathrm{~Pb}$ shot did not affect egg production (Finley and Dieter 1978); a dose of 1 number $8 \mathrm{~Pb}$ shot caused some mortality in mourning doves (Zenaida macroura) and reduced fertility but did not reduce productivity (Buerger et al. 1986); studies on kestrels (Falco sparverius) fed up to $50 \mathrm{mg} \mathrm{Pb} / \mathrm{kg}$ (Pattee 1984) and on ringed turtle doves (Streptopelia risoria) fed up to $10 \mu \mathrm{g} \mathrm{Pb} / \mathrm{mL}$ of water (Kendall and Scanlon 1981) also detected no reduction in productivity. We conclude that although Japanese quail provide a useful model for studying the kinetics of $\mathrm{Pb}$ in birds and hematological endpoints (ALAD, protoporphyrin), they seem to be a poor surrogate species for wild birds in general in ecological risk assessments of $\mathrm{Pb}$.

\section{Relation of blood $\mathrm{Pb}$ concentrations to dietary $\mathrm{Pb}$ concentrations in birds}

The regression of the concentration of a contaminant in blood to an external dose provides a means to relate environmental exposure to the internal, or absorbed, dose. Knowing the absorbed dose is useful for evaluating both exposure and potential toxic effects.

The relation between blood $\mathrm{Pb}$ concentration and dietary $\mathrm{Pb}$ concentration has been more thoroughly studied in mammals than in birds. Researchers studying mammals have found greater relative absorption of $\mathrm{Pb}$ from the diet at low concentrations, leading to a concave (decreasing slope) curvilinear relation (ATSDR 2007). This greater absorption may be caused by active absorption of $\mathrm{Pb}$ associated with $\mathrm{Ca}$ transport across the gut. At higher concentrations of $\mathrm{Pb}$, saturation of red blood cells with $\mathrm{Pb}$ may occur (ATSDR 2007). In contrast, however, the regressions of $\mathrm{Pb}$ in blood, liver and kidneys for Japanese quail are all linear. Previous studies on waterfowl fed $\mathrm{Pb}$-contaminated river sediments from the Coeur d'Alene River Basin also suggest a linear relation for birds, even at blood $\mathrm{Pb}$ concentrations as high as $6 \mathrm{mg} \mathrm{Pb} / \mathrm{kg}$, wet wt (Beyer et al. 2000). It is possible that increased absorption of $\mathrm{Pb}$ could occur at a very low exposure but, for the purposes of risk assessment, it is reasonable to assume linearity, which simplifies modeling of $\mathrm{Pb}$ in birds.

In studies meant to protect humans from $\mathrm{Pb}$, risk assessors often rely on the "intake slope factor," which is the slope of the regression of blood $\mathrm{Pb}$ concentration to dose. Sometimes this parameter is replaced by the product of the estimated fraction of $\mathrm{Pb}$ absorbed (bioavailability) and the "biokinetic slope factor," which depends on the kinetics of $\mathrm{Pb}$ once it is absorbed and interacts with blood (ATSDR 2007). Intake slopes for human health are expressed as the weight of $\mathrm{Pb}$ consumed, rather than on the concentration in the diet, as in our study, which prevents the direct comparison between the intake slope and our blood-dietary slope. Because assessment models for humans are designed to protect the most susceptible children in a population, the laboratory studies supporting the assessments generally exposed animals to $\mathrm{Pb}$-contaminated soil on an empty stomach, which increased the rate of absorption. Humans were found to absorb $8.2 \%$ of a dose of $\mathrm{Pb}$ taken with food and 35\% of a dose of $\mathrm{Pb}$ taken without food (Rabinowitz et al. 1980). In contrast, we assumed that wild birds would ingest soil mainly while feeding and incorporated contaminated soil into the diet.

The blood-dietary $\mathrm{Pb}$ slope for our Japanese quail of 0.0027 (mg Pb/kg blood [wet wt] $\div \mathrm{mg} \mathrm{Pb/kg} \mathrm{diet)} \mathrm{was} \mathrm{similar} \mathrm{to} \mathrm{most}$ 
of the other slopes shown in Table 4, which were generally between 0.0025 and 0.0053 .

The variation is well below that associated with toxicity reference values of $\mathrm{Pb}$ (USEPA 2005). The consistency among the values was unexpected, given the range of species and the variety of experimental exposures in the studies. We do not know how much of the total variation in these values is associated with each of the variables expected to be relevantthe species, diet, and bioavailability of the $\mathrm{Pb}$. The blooddietary $\mathrm{Pb}$ slope should vary directly with the bioavailability of the $\mathrm{Pb}$, which depends on the chemical form of the $\mathrm{Pb}$, as well as on the chemical properties of food and soil that inhibit absorption from the gut. Hoffman et al. (2000a) reported that $\mathrm{Pb}$ from contaminated sediment in feed was $44 \%$ as available as $\mathrm{Pb}$ acetate in feed when fed to ducklings. Blood $\mathrm{Pb}$ concentrations were found to be greater when waterfowl were fed suboptimal diets (Hoffman et al. 2000a; Day et al. 2003), possibly due to nutritional deficiencies, such as a reduced level of Ca (Scheuhammer 1996), or to a greater rate of ingestion. Compounds may bind $\mathrm{Pb}$ to soil and sediment; the addition of phosphoric acids to $\mathrm{Pb}$-contaminated sediments decreased the rate of absorption by subadult mallards (Heinz et al. 2004; Furman et al. 2006). If the relative bioavailability of $\mathrm{Pb}$ in a soil were known, then the blood-dietary $\mathrm{Pb}$ slope could be adjusted for use in risk assessment.

Ecological risk assessments generally relate a toxicity reference value to an estimated exposure. However, if an exposure to $\mathrm{Pb}$ had been estimated, then the blood $\mathrm{Pb}$ concentration could be estimated from the blood-dietary $\mathrm{Pb}$ slope and the toxicity could be estimated with a tissue residue approach; Buekers et al. (2009) have gathered together critical blood $\mathrm{Pb}$ values for many avian species and Franson and Pain (2011) have reviewed the topic of interpreting $\mathrm{Pb}$ concentrations in avian tissues. Supplementing a risk assessment based on toxicity reference values with a tissue-residue approach as a second line of evidence should reduce the uncertainty associated with a risk assessment. Estimates of exposure at contaminated sites are generally made from biomagnification factors in the literature or rarely by analyzing dietary items, stomach contents or fecal samples. If the blood-dietary slope for a bird were known, then analyzing avian blood from a contaminated site would provide a means to estimate exposure as well as to ground-truth an assessment. When collecting and analyzing blood samples from the field, it is important to include those species that are expected to ingest the most soil. The length of time the birds have been present and the soil $\mathrm{Pb}$ concentrations throughout the feeding range are relevant. Although the blood $\mathrm{Pb}$ concentrations from the field should integrate exposure across a heterogeneous site, the variability in blood $\mathrm{Pb}$ concentrations in birds from the field would be expected to be much greater than that observed under controlled conditions and so it is important to have an adequate sample size. Significant species-specific differences in blooddietary slopes would introduce errors into the estimates of exposure.

Because the blood-dietary $\mathrm{Pb}$ slope is based on soil ingestion, we may also predict the soil ingestion rate, using $\mathrm{Pb}$ as a tracer for soil if we know the mean blood $\mathrm{Pb}$ concentration and the soil $\mathrm{Pb}$ concentration at a site. This would provide us with a means to estimate a bird's exposure to other metals, such as $\mathrm{U}, \mathrm{Ni}, \mathrm{Fe}$, or $\mathrm{Al}$, whose main pathway of exposure is also mainly through soil ingestion; the exposure to $\mathrm{Al}$, for example, would be simply the ratio of the soil concentrations of $\mathrm{Al}$ to $\mathrm{Pb}$ multiplied by the exposure to $\mathrm{Pb}$. This simple method could be especially useful at the screening level in risk assessments when several contaminants are considered.

Acknowledgment-We thank Rebecca Lazarus for calculating the benchmarks for $\mathrm{Pb}$ and for help in running biochemical assays. Funding for this work was provided by the US Geological Survey. Mention of a proprietary product does not constitute a guarantee or warranty of the product by the US Geological Survey or the US Fish and Wildlife Service by the authors and does not imply its approval to the exclusion of other products that may also be suitable.

\section{REFERENCES}

Almansour M. 2008. Histological and histochemical alterations induced by lead in the kidney of the quail Coturnix coturnix. Saudi J Biol Sci 15:307313.

Anders E, Dietz D, Bagnell C, Gaynor J, Krigman M, Ross D, Leander J, Mushak P. 1982. Morphological, pharmacokinetic, and hematological studies of leadexposed pigeons. Environ Res 28:344-363.

[ATSDR] Agency for Toxic Substances and Disease Registry. 2007. Toxicological profile for lead. Atlanta (GA): US Department of Health and Human Services.

Bakalli R, Pesti G, Ragland W. 1995. The magnitude of lead toxicity in broiler chickens. Vet Hum Toxicol 37:15-19.

Bannon DI, Parsons PJ, Centeno JA, Lal S, Xu H, Rosencrance AB, Dennis WE, Johnson MS. 2011. Lead and copper in pigeons (Columbia livia) exposed to a small arms-range soil. Arch Environ Contam Toxicol 60:351-360.

Besser J, Brumbaugh W, May T, Schmitt C. 2007. Biomonitoring of lead, zinc, and cadmium in streams draining lead-mining and non-mining areas, southeast Missouri, USA. Environ Monit Assess 129:227-241.

Beyer W, Audet D, Heinz G, Hoffman D, Day D. 2000. Relation of waterfowl poisoning to sediment lead concentrations in the Coeur d'Alene River Basin. Ecotoxicology 9:207-218.

Beyer WN, Spann JW, Sileo L, Franson JC. 1988. Lead poisoning in six captive avian species. Arch Environ Contam Toxicol 17:121-130.

Brumbaugh WG, May TW, Besser JM, Allert AL, Schmitt CJ. 2007. Assessment of elemental concentrations in streams of the New Lead Belt in southeastern Missouri, 2002-05. Reston (VA): US Geological Survey. Scientific Investigations Report 2007-5057.

Brumbaugh WG, Schmitt CJ, May TW. 2005. Concentrations of cadmium, lead, and zinc in fish from mining-influenced waters of northeastern Oklahoma: Sampling of blood, carcass, and liver for aquatic biomonitoring. Arch Environ Contam Toxicol 49:76-88.

Buekers J, Steen Redeker E, Smolders E. 2009. Lead toxicity to wildlife: Derivation of a critical blood concentration for wildlife monitoring based on literature data. Sci Total Environ 407:3431-3438.

Buerger TT, Mirarchi RE, Lisano ME. 1986. Effects of lead shot ingestion on captive mourning dove survivability and reproduction. J Wildl Manag 50:1-8.

Burch H, Siegel A. 1971. Improved method for measurement of delta-aminolevulinic acid dehydratase activity in human erythrocytes. Clin Chem 17:10381041.

Burger J, Gochfeld M. 1997. Age differences in metals in the blood of herring (Larus argentatus) and Franklin's (Larus pipixcan) gulls. Arch Environ Contam Toxicol 33:436-440.

Casteel S, Weis C, Henningsen G, Brattin W. 2006. Estimation of relative bioavailability of lead in soil and soil-like materials using young swine. Environ Health Perspect 114:1162-1171.

Connor E, Scanlon P, Kirkpatrick R. 1994. Bioavailability of lead from contaminated sediment in northern bobwhites, Colinus virginianus. Arch Environ Contam Toxicol 27:60-63.

Day D, Beyer W, Hoffman D, Morton A, Sileo L, Audet D, Ottinger M. 2003. Toxicity of lead-contaminated sediment to mute swans. Arch Environ Contam Toxicol 44:510-522.

Edens F, Benton E, Bursian S, Morgan G. 1976. Effect of dietary lead on reproductive performance in Japanese quail, Coturnix coturnix japonica. Toxicol Appl Pharmacol 38:307-314.

Edens F, Garlich J. 1983. Lead-induced egg production decrease in leghorn and Japanese quail hens. Poult Sci 62:1757-1763. 
Filipsson AF, Sand S, Nilsson J, Victorin K. 2003. The benchmark dose methodreview of available models, and recommendations for application in health risk assessment. Crit Rev Toxicol 33:505-542.

Finley M, Dieter M. 1978. Influence of laying on lead accumulation in bone of mallard ducks. J Toxicol Environ Health 4:123-129.

Finley MT, Dieter MP, Locke LN. 1976. Sublethal effects of chronic lead ingestion in mallard ducks. J Toxicol Environ Health 1:929-937

Franson J, Haramis G, Perry M, Moore J. 1986. Blood protoporphyrin for detecting lead exposure in canvasbacks. In: Felerabend JS, Russell AB, editors, Lead poisoning in wild waterfowl-A workshop. Washington DC: National Wildlife Federation. p 32-37.

Franson JC, Pain D. 2011. Lead in birds. In: Beyer WN, Meador J, editors, Environmental contaminants in biota: Interpreting tissue concentrations. Boca Raton (FL): CRC. p 563-594.

Furman O, Strawn D, Heinz G, Williams B. 2006. Risk assessment test for lead bioaccessibility to waterfowl in mine-impacted soils. J Environ Qual 35: 450-458.

Hansen J, Audet D, Spears B, Healy K, Brazzle R, Hoffman D, Dailey A, Beyer W. 2011. Lead exposure and poisoning of songbirds using the Coeur d'Alene River Basin, Idaho, USA. Integr Environ Assess Manag 7:587-595.

Heinz G. 1999. Toxicity of lead-contaminated sediment to mallards. Arch Environ Contam Toxicol 36:323-333.

Heinz G, Hoffman D, Audet D. 2004. Phosphorus amendment reduces bioavailability of lead to mallards ingesting contaminated sediments. Arch Environ Contam Toxicol 46:534-541.

Henny C, Blus L, Hoffman D, Grove R. 1994. Lead in hawks, falcons and owls downstream from a mining site on the Coeur d'Alene River, Idaho. Environ Monit Assess 29:267-288.

Henny C, Blus L, Hoffman D, Grove R, Hatfield J. 1991. Lead accumulation and osprey production near a mining site on the Coeur d'Alene River, Idaho. Arch Environ Contam Toxicol 21:415-424.

Henny C, Blus L, Hoffman D, Sileo L, Audet D, Snyder M. 2000. Field evaluation of lead effects on Canada geese and mallards in the Coeur d'Alene River Basin, Idaho. Arch Environ Contam Toxicol 39:97-112.

Henry P, Akuffo VG, Chen Y, Karouna-Renier NK, Sprague DT, Bakst MR. 2012. Effect of $17 \beta$-trenbolone on male and female reproduction in Japanese quail (Coturnix japonica). Avian Biol Res 5:61-68.

Hill EF, Camardese MB. 1986. Lethal dietary toxicities of environmental contaminants and pesticides to Coturnix. Washington DC: US Fish and Wildlife Service. Technical Report 2

Hoffman D, Heinz G, Sileo L, Audet D, Campbell J, LeCaptain L. 2000a. Developmental toxicity of lead-contaminated sediment to mallard ducklings. Arch Environ Contam Toxicol 39:221-232.

Hoffman DJ, Heinz GH, Sileo L, Audet DJ, Campbell JK, Obrecht HH III. 2000b. Developmental toxicity of lead-contaminated sediment in Canada geese (Branta canadensis). J Toxicol Environ Health 59:235-252.

Johnson M, Wickwire W, Quinn M Jr, Ziolkowski D Jr, Burmistrov D, Menzie C, Geraghty C, Minnich M, Parsons P. 2007. Are songbirds at risk from lead at small arms ranges? An application of the spatially explicit exposure model. Environ Toxicol Chem 26:2215-2225.

Kendall RJ, Scanlon PF. 1981. Effects of chronic lead ingestion on reproductive characteristics of ringed turtle doves (Streptopelia risoria) and on tissue lead concentrations of adults and their progeny. Environ Pollut Ser A Ecol Biol 26:203-213.

McBride T. 2007. Influence of metal mixtures on co-occurring toxic metal bioavailability and effects in adult and developing deer mice [thesis]. Lubbock (TX): Texas Tech.

Mielke HW, Reagan PL. 1998. Soil is an important pathway of human lead exposure Environ Health Perspect 106:217-229.

Morgan G, Edens F, Thaxton P, Parkhurst C. 1975. Toxicity of dietary lead in Japanese quail. Poult Sci 54:1636-1642.

Natural Resource Damage Assessment (15 C. F. R. § 11.62 (f) (4) (v) (D)(1995)).

O'Connell M, Rees E, Einarsson O, Spray C, Thorstensen S, O'Halloran J. 2008. Blood lead levels in wintering and moulting Icelandic whooper swans over two decades. J Zool 276:21-27.

Pain D. 1987. Hematological parameters as predictors of blood lead and indicators of lead poisoning in the black duck. Environ Pollut 60:67-81.

Pattee OH. 1984. Eggshell thickness and reproduction in American kestrels exposed to chronic dietary lead. Arch Environ Contam Toxicol 13:29-34.

Rabinowitz MB, Kopple JD, Wetherill GW. 1980. Effect of food intake and fasting on gastrointestinal lead absorption in humans. Am J Clin Nutr 33:1784-1788.

Rattner B, Golden N, Toschik P, McGowan P, Custer T. 2008. Concentrations of metals in blood and feathers of nestling ospreys (Pandion haliaetus) in Chesapeake and Delaware Bays. Arch Environ Contam Toxicol 54:114-122.

Roscoe D, Nielsen S, Lamola A, Zuckerman D. 1979. A simple, quantitative test for erythrocytic protoporphyrin in lead-poisoned ducks. J Wildl Dis 15:127-136.

Scheuhammer A. 1996. Influence of reduced dietary calcium on the accumulation and effects of lead, cadmium, and aluminum in birds. Environ Pollut 94:337-343.

Shacklette H, Boerngen J. 1984. Element concentrations in soils and other surficial materials of the conterminous United States. Washington DC: US Geological Survey. Professional Paper 1270

Smith K, Abrahams P, Dagleish M, Steigmajer J. 2009. The intake of lead and associated metals by sheep grazing mining-contaminated floodplain pastures in mid-Wales, UK: I. Soil ingestion, soil-metal partitioning and potential availability to pasture herbage and livestock. Sci Total Environ 407:3731-3739.

[USEPA] US Environmental Protection Agency. 1997. Method 3051a: Microwave assisted acid dissolution of sediments, sludges, soils and oils. 2nd ed. U. S. Gov. Print. Office, Washington DC.

[USEPA] US Environmental Protection Agency. 2003. Guidance for developing ecological soil screening levels (EcO-SSLS). Washington DC: USEPA. OSWER Directive 92857-55.

[USEPA] US Environmental Protection Agency. 2005. Ecological soil screening levels for lead: Interim final. Washington DC: USEPA. OSWER Directive 9285.7-70.

Wayland M, Scheuhammer A. 2011. Cadmium in birds. In: Beyer W, Meador J, editors. Environmental contaminants in biota: Interpreting tissue concentrations. Boca Raton (FL): CRC. p 645-666. 